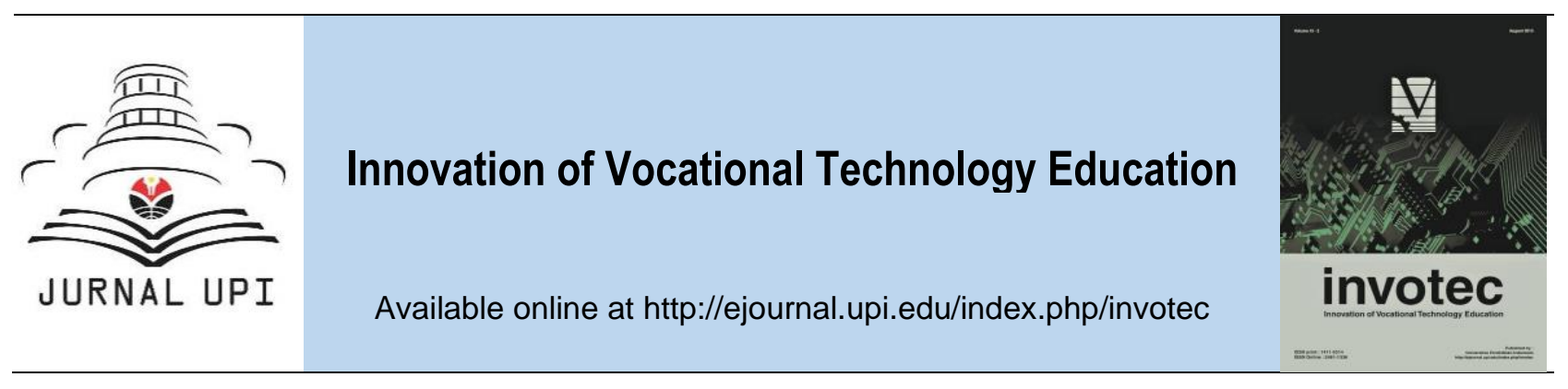

\title{
Effect of Problem-Based Learning on Students' Academic Achievement in Digital Electronics in Ken Saro-Wiwa Polytechnic, Bori, Rivers State, South-South, Nigeria
}

\author{
Owo Offia Tugwell \\ Department of Vocational and Technology Education, Rivers State University, Port Harcourt, Nigeria
}

\section{ARTICLE INFO}

Article history:

Received: 05 November 2019

Received in revised form: 17 December 2019

Accepted: 28 January 2020

Available online: 29 February 2020

Keywords:

academic achievement;

conventional teaching;

problem-based learning;

student;

technology-based courses

Authors email:

offia.owo1@ust.edu.ng

\begin{abstract}
The study investigated the effect of Problem-Based Learning (PBL) on Students' Academic Achievement in Digital Electronics in Ken Saro-Wiwa Polytechnic, Bori, Rivers State, South-South, Nigeria. Quasi-experimental pre-test post-test control design was used in the study. The sample of the study comprised 84 Higher National Diploma (HND) final year students of electrical and electronic engineering (Telecommunications and electronics option). Three research questions and one hypothesis were formulated and tested at 0.05 level of significance guided the study. The instrument used for data collection was a 20-item Digital Electronics Achievement Test Questionnaire (DEATQ) designed by the researcher and validated by two experts in electrical and electronic engineering from Federal Polytechnic, Nekede, Owerri, Imo State. Kuder-Richardson formula was used to obtain the instrument's reliability coefficient as 0.87 . Mean and t-test were used to answer the research questions and test the hypothesis at 0.05 level of significance. The findings of the study revealed among others that problem-based learning enhances students' academic achievement in Digital Electronics. Consequently, it was recommended among others that engineering technology lecturers in Nigerian polytechnics and universities should use more of PBL and other student-centred teaching strategies in instructional delivery in order to boost students' achievement in technology-based courses.
\end{abstract}

\section{Introduction}

\subsection{Significance of the main topics}

Digital electronics is one of the accredited courses by the National Universities Commission (NUC) and the National Board for Technical Education (NBTE) for university and polytechnic undergraduate programmers in Electrical/Electronic Engineering, Computer Science, Information Technology, Technology Education and Physics Electronics. According to the National Board for Technical Education (NBTE) (2001), Electrical/Electronic Engineering Higher National Diploma (HND) students whose area of specialization is electronics and telecommunications are to 
compulsorily study and pass Digital Electronics as one of the requirements for graduation. Digital Electronics refers to electronic systems that represent signals in discrete quantities (Chukwudebe, Chika, \& Onojo, 2006). According to Vanwasi and Mithal (2004), digital systems operate only on two voltage levels of either HIGH or LOW having numerical equivalents of (5 or 3) $\mathrm{V}$ and $0 \mathrm{~V}$ respectively. Digital systems are easy to design and analyses since they operate only on two distinct voltage levels and as such they have numerous advantages over analogue systems (Sedha, 2010). Some of the major advantages of digital systems are reduced noise, steady output, reduced bandwidth, accuracy, reliability, data integrity, information security among others (Chukwudebe, Chika, \& Onojo, 2006). At the introductory stage, the course contents of Digital Electronics include number systems, computer and binary Arithmetic, logic gates, combinational and sequential circuits, adders, counters and electronic registers among others (Floyd, 2002). Digital electronics systems are very essential in today's world of technology as the world is becoming fully digitalized (Jones, 1996). The world is referred to as a global village because of innovations in information and communication technology in which digital electronics systems are key components. The study of Digital electronics at the undergraduate level is done by students of electrical and electronic engineering (telecommunications and electronics option, technology education (electrical/electronic option), Computer Science, Information management technology and Electronics Physics. Digital Electronics is a course having both theoretical and practical contents and as such warrants lecturers and instructors to apply appropriate teaching methods and strategies to enable students learn effectively. Therefore, polytechnic and university lecturers handling Digital Electronics as a technical course needs adequate knowledge, skills and practical hands-on experience to be able to fast track effective instructional delivery of course contents as specified by the NBTE and NUC curricula. Appropriate learner-centered teaching methods and strategies tend to enhance students' learning of technical courses resulting in improved students' academic achievement in such courses.

However, the reverse is the case as Digital electronics at universities and polytechnics in Nigeria is being handled using more of conventional (lecture) teaching method which yields little or no academic achievements in the course. This is because students may not have seen most of the things (devices and equipment) mentioned by the lecturer theoretically and as such will not show much interest and enthusiasm in the lesson. This may probably limit students' ability to acquire the relevant skills in such technical areas. Conventional teaching method makes learners become passively involved in the teaching-learning process as they would sit quietly in the class and receive whatever information given by lecturers as lectures. In other words, they cannot add or contribute to the teaching-learning process since the teacher only gives out information. According to Felder and Brent (1994), conventional teaching method constitutes a loss for both the teachers who apply it in technical courses instruction as well as the students they teach. Since conventional method of teaching do not allow students to be actively involved in the instructional process, their ability to construct their own learning becomes poor thus, there is a great need for the use of student-centred learning methods in teaching technical courses. Student- centered learning methods such as 
Problem Based Learning, Constructivist Learning, Collaborative Learning among others enable learners (students) to engage in active learning by contributing and sharing of valuable ideas capable of proffering solutions to any technological or engineering issues they are faced with.

Students' achievement in technical and engineering courses in tertiary institutions has been an issue that concerns educational planners, teachers, parents and students. Applying the appropriate student-centered instructional methods is believed to facilitate students' academic achievements in technical areas since it will enhance their psychomotor (skill development) abilities and subsequently, boost creativity and innovativeness in the students resulting to the technological advancement of the nation. Student-centered teaching methods are result-oriented strategies adopted by lecturers and instructors to encourage students' learning and overall academic achievement through adequate development of problem-solving skills (Ekezie \& Owo, 2019). Problem-based learning ( $\mathrm{PBL}$ ) as one of the student-centred learning methods emphasizes the significance of affective properties of students as well as cognitive and psychomotor properties in order to realize improved students' overall academic achievement. PBL has an integrative structure incorporating cognitive, affective and psychomotor learning domains in the teaching-learning process for improved students' performance academically (Walton and Matthews, 1989). In the same vein, Barrows (2002) describes PBL as a teaching method which enhances the development of problem-solving abilities of students leading to knowledge acquisition and accumulation in diverse areas of education and allied disciplines. In the views of Edens (2000), PBL approach exposes students to creative thinking and quality research that yields results. Furthermore, Johnstone and Biggs (1998) opine that PBL is a student-oriented teaching that inculcates in the students, problem solving skills and innovativeness which can be applied to solve real life problems. PBL refers to a student-oriented approach that requires learners to conduct research, apply theory and practice to finding solutions to well-defined practical problems using their personal knowledge and skills acquired from in-depth independent study (Savery, 2006).

Tseng, Chiang, and Hsu (2008), report that in problem-based learning, students do not only learn the subject, but they also acquire knowledge transfer skills, taking responsibility for their own life-long learning. Furthermore, Arends (1998), stated that the purpose of PBL approach is, to reach the very essence of the subject (course) after the students must have carried out quality research to acquire knowledge and skills transferrable to different fields. In PBL, students develop their creative, communication and teamwork skills in relation to the acquisition of technical skills thereby, applying appropriate competences to work (Mierson \& Parikh, 2000). According to Kaptan and Korkmaz (2001), PBL has positive effects on students' attitudes like learning interests and level of curiosity. The effectiveness of PBL is observed in such important areas as development of students' affective properties, such as attitude toward courses, desire and motivation, making knowledge permanent, and acquiring skills like problem solving, updating knowledge, and doing research (Kaufman \& Mann, 1997; Sifoğlu, 2007). Delisle (1997) describes PBL as an active learning approach that plays a significant role of enhancing students' interest in learning and overall academic achievement. PBL 
applications teach students how to work collectively as a team for improved performance through adequate development of high-level cognitive skills such as analysis, synthesis and assessment necessary for problem solving (Uden, 2006). PBL helps to determine the development of skills like thinking and establishing cause-effect relationships (House, 2000; Saban, 2004). This approach, which allows students to work actively as teams on a pre-defined problem, provides opportunities for students to develop their critical thinking skills (Hastings, 2003). Adequate application of PBL in the teaching-learning process helps students to understand and interpret knowledge, configure knowledge, achieve internal motivations and become rational individuals (Beringer, 2007; Dooley, 1997; Duch, Groh, \& Alen, 2001; Hmelo-Silver, 2004).

\subsection{Previously related studies}

Problem-based learning as a teaching strategy was found to have much relevance in the fields of medicine, social sciences, education, engineering, architecture, management, law, economics, administration, mathematics, natural sciences, agriculture among others (Demirel \& Dağyar, 2016). According to Schwarts, Mennin, and Webb (2001), PBL was introduced in schools as a result of its efficacy in the teaching-learning processes. PBL was first introduced at McMaster University Medical School, Canada, in the late 1960s as an instructional method that was later included in the literature. By 1970s, PBL was already applied in several medical schools across the globe. Demirel and Dağyar (2016) reports that the number of schools that adapted PBL as a teaching-learning approach rises annually due to its student-centred oriented instructional approach capable of promoting students' academic achievements. Problem-based learning was found to assisting students in conceptualizing diverse engineering fundamentals (Santos-Martin et al., 2012). In a study by Ribeiro and Mizukami (2005), PBL was found to enhance students' capacity to finding solutions to several engineering problems. PBL also helps to build students' attitudes in many key skill areas of problem-solving, thinking, teamwork, communication, information acquisition and information dissemination (Akınoğlu \& Tandoğan, 2007).

Thus, from the 20th century to this date, PBL has never lost its importance in the teachinglearning process. Before now, several studies were carried out by experts and researchers in the field of education to investigate the effects of PBL on students' academic performance (achievement and skills), teacher satisfaction and students' attitude towards the attainment of educational objectives (Albanese \& Mitchell, 1993; Leary, 2012; Walker \& Leary, 2009). Today, the growth and application of $\mathrm{PBL}$ continues, and this trend reassures researchers to carryout numerous studies to ascertain its effectiveness in different technical and engineering subjects. Due to an increasing recognition of the importance of affective domain to students' learning, several independent studies have been conducted by experts to determine PBL's effects on students' attitudes towards their educational advancement and the outcome records that PBL has positive effect on students' learning (Çelik, Eroğlu, \& Selvi, 2012). 
However, different researchers have divergent views about PBL's effect on students' performance based on the results they obtained from their respective studies. For instance, in some studies, scholars argued that PBL has positive effects on attitude (Abdullah, Tarmizi, \& Abu, 2010; Marum, 2009; Tavukçu, 2006), whereas in some other studies, the findings revealed that PBL has no effects or negative effects on students' attitude (Koçakoğlu, 2008; Özdil, 2011; Reynolds \& Hancock, 2010; Sevening \& Baron, 2003). In another study by Swart (2014) titled "Using ProblemBased Learning to Stimulate Entrepreneurial Awareness Among Senior African Undergraduate Students", it was found that students are able to engage in problem-based learning in engineering, but they lacked the capability to design an effective sales poster which forms part of entrepreneurial skills. The findings of the study further indicated that the students were able to meet the learning outcomes for any practical assignments and really enjoyed the problem-based learning approach after it was introduced and applied by teachers.

Similarly, in a related report by Engineering Council of South Africa (ECSA) (2014), problembased learning is used extensively in National Diploma courses in Electrical Engineering in South Africa, where students need to complete approximately 22 courses over a 2-year period after which an additional year must be spent in industry, where students do some practical works based on direct application of the theoretical knowledge they acquired at school. The additional year of vocational training which may be referred to as work based experience or work integrated learning (WIL) is mandated by the Engineering Council of South Africa (ECSA), a statutory body responsible for promoting a high level of education and training of practitioners in the engineering profession (ECSA, 2014). PBL as an active teaching-learning approach enhances students' ability to develop relevant skills applicable in the industry for employment anchored on creativity and constant practice. Thus, students' academic achievements in engineering and technology-based courses to a large extent depends on the instructional strategies applied by lecturers and instructors. Any instructional or teaching method that involves the students as active participants of the teaching-learning process is regarded as student-centred approach and as such should be applied by teachers and lecturers in delivering engineering instructions to students since it enhances skills development and creativity. Habitual application of problem-based learning and other student-centered instructional methods is believed to promote students' advancement presently and in future.

\subsection{Purpose and research gap of the study}

The main purpose of this study was to determine the effects of problem-based learning on students' academic achievement in Digital electronics in Ken Saro-Wiwa Polytechnic, Bori, Rivers State, South-South, Nigeria. In other words, the study was aimed at testing the instructional delivery approaches adopted by lecturers for teaching engineering and technology courses in polytechnics in Rivers State. This is because effective teaching and learning in schools lead to improved students' academic achievements and application of wrong teaching methods could also impede on students' ability to learn effectively thereby reduced their overall achievement. Hence, the need to ascertain 
the effects of problem-based learning on students' academic achievement in Digital electronics in Ken Saro-Wiwa Polytechnic, Bori, Rivers State, South-South, Nigeria is inevitable. In recent times, the academic achievement of students in technical and engineering courses in Nigerian tertiary institutions was observed to be very low leading to poor skill development of students (Diraso et al., 2013). Several factors could cause the academic achievements of students in electrical/electronic engineering courses including Digital electronics to be very low. According to Fajimi (2005), one major factor responsible to poor students' achievement in educational institutions is the use of inappropriate instructional methods. Students' ability to reason effectively and solve problems creatively are skills that must be acquired through appropriate instruction and training (Swart, 2010). The use of conventional teaching (lecture) method in instructional delivery in technical courses was found to yield little or no improvement in students' learning since it is teacher-centred (Okwelle \& Owo, 2018). Conventional method which is one of the teacher-centred approaches causes the learner to be passively involved in the teaching-learning process which results in poor achievements. It therefore becomes imperative to adopt more pragmatic student-centred teaching strategies for instructional delivery in Digital electronics. Learner-centred teaching methods are capable of ensuring active participation of students in teaching-learning activity thus, enabling them to construct their own learning through creative thinking and innovativeness. One of the student-centred teaching method capable of promoting students' learning and overall academic achievement is problembased learning (PBL). Problem-based learning has helped students to conceptualize different engineering fundamentals (Bhatti \& McClellan, 2011). Consequently, this study was conducted to ascertain the effects of problem-based learning on students' academic achievement in Digital electronics in Ken Saro-Wiwa Polytechnic, Bori, Rivers State, South-South, Nigeria.

\subsection{Research questions}

- What is the post-test Mean scores of students taught Digital electronics using conventional teaching method and Problem-based learning in Ken Saro-Wiwa Polytechnic, Bori, Rivers State, South-South, Nigeria?

- What is the pre-test and post-test Mean scores of students taught Digital electronics using Problem-based learning in Ken Saro-Wiwa Polytechnic, Bori, Rivers State, South-South, Nigeria?

- What is the mean gain difference in the scores of students taught Digital electronics using Problem-based learning and conventional teaching method in Ken Saro-Wiwa Polytechnic, Bori, Rivers State, South-South, Nigeria? 


\subsection{Hypothesis}

There is no significant difference between the post-test Mean scores of students taught Digital electronics using conventional teaching method and Problem-based learning in Ken Saro-Wiwa Polytechnic, Bori, Rivers State, South-South, Nigeria.

\section{Materials and Methods}

The study adopted quasi-experimental pre-test post-test control design which compared a control group using conventional teaching method with an experimental group using problem-based learning to ascertain the effects of problem-based learning on students' academic achievement in Digital electronics in Ken Saro-Wiwa Polytechnic, Bori, Rivers State, South-South, Nigeria. The population of the study comprised 84 Higher National Diploma (HND) final year students of electrical and electronic engineering technology who specialized in telecommunications and electronics during the 2018/2019 academic session. No sampling was done since the population was small and manageable. Three research questions and one hypothesis formulated and tested at 0.05 level of significance guided the study. The 84 telecommunications and electronics students were equally shared into two groups of which one is called the control group and the other, the experimental group respectively. The control group has 42 students and again the experimental group has 42 students too. The instrument used for data collection was a 20 -item Digital Electronics Achievement Test Questionnaire (DEATQ) designed by the researcher based on the Higher National Diploma (HND) Digital Electronics Curriculum of the National Board for Technical Education (NBTE). The test questions were constructed on the following core topics in Digital Electronics: Digital systems overview, Advantages of Digital systems over Analogue systems, Number Systems, Computer and Binary Arithmetic, 1's and 2's complements, Logic Gates, Boolean Algebra, Integrated Circuits, Combinational and Sequential Logic Circuits, Digital Circuit Design and Analysis, Flip-flops and Latches, Electronic Counters, Registers and their applications. Two experts in electrical and electronic engineering from Federal Polytechnic, Nekede, Imo State validated the test instrument whose reliability coefficient was obtained as 0.89 via Kuder- Richardson formula. Two research assistants helped the researcher in carrying out the study. In conducting the experiment, the researcher having acquired theoretical knowledge and practical skills in Digital Electronics administered a pre-test to both the control and experimental groups and record the mean scores of both groups. The control group was then taught Digital electronics using conventional teaching method and a post-test was given to them in which the mean scores obtained from the test was noted. Similarly, the experimental group received treatment in the form of Problem-based learning which culminates in the administration of a post-test on the group after which the mean score obtained was also recorded. The research which was conducted during the 2018/2019 academic session of the polytechnic lasted for a period of six weeks. Mean was the descriptive statistical tool 
used to analyze the three research questions meanwhile t-test was the inferential statistics adopted to test the null hypothesis at 0.05 level of significance.

\section{Results and Discussion}

\subsection{Results}

The results of the study were stated in accordance with the three research questions and hypothesis as follows:

- Research Question 1: What are the post-test Mean scores of students taught Digital electronics using conventional teaching method and Problem-based learning in Ken SaroWiwa Polytechnic, Bori, Rivers State, South-South, Nigeria?

- Research Question 2: What are the pre-test and post-test Mean scores of students taught Digital electronics using Problem-based learning in Ken Saro-Wiwa Polytechnic, Bori, Rivers State, South-South, Nigeria?

- Research Question 3: What is the post-test mean gain difference in the scores of students taught Digital electronics using problem-based learning and conventional method in Ken SaroWiwa Polytechnic, Bori, Rivers State, South-South, Nigeria?

- Hypothesis: There is no significant difference between the post-test Mean scores of students taught Digital electronics using conventional teaching method and Problem-based learning in Ken Saro-Wiwa Polytechnic, Bori, Rivers State, South-South, Nigeria.

\subsection{Discussion}

The findings of the study in table 1 revealed that the students taught Digital electronics using Problem-based learning performed far better than the ones taught same course using Conventional teaching method. This finding corroborates the views of the Engineering Council of South Africa (2014) which reports that Problem-based learning helps students to apply acquired theoretical knowledge to proffer solutions to everyday technological problems in the industry. Similarly, this finding shares the views of Swart (2014) who reports that Problem-based learning improves the proficiency of engineering students. Furthermore, this finding agrees with the separate reports of Colliver (2000), Leary (2012), and Üstün (2012) which succumb that PBL approach is more effective on students' attitudes toward courses leading to improved performance than conventional teaching method. 
invotec XVI:1 (2020) 62-75

Table 1. Pre-test and post-test mean scores of students' performance in digital electronics

\begin{tabular}{|c|c|c|c|c|c|}
\hline Group & Treatment & Population(n) & $\begin{array}{c}\text { Pre-test } \\
\text { Mean }\end{array}$ & $\begin{array}{c}\text { Post-test } \\
\text { Mean }\end{array}$ & $\begin{array}{l}\text { Mean } \\
\text { Gain }\end{array}$ \\
\hline Experimental & $\begin{array}{l}\mathrm{PBL} \\
\text { Lecture }\end{array}$ & 42 & 7.81 & 14.41 & 6.6 \\
\hline Control & Method & 42 & 7.91 & 11.71 & 3.8 \\
\hline
\end{tabular}

Table 1 showed the pretest and post-test mean scores of both the experimental group and the control group. While the post-test mean of the experimental group was obtained as 14.41 , that of the control group was seen as 11.71. Table 2 revealed that the pre-test Mean of the experimental group was 7.81 while the post-test Mean when PBL was applied as treatment on the group was obtained as 14.41 .

Table 2. Pre-test and post-test mean scores of students taught digital electronics via PBL

\begin{tabular}{llllll}
\hline Group & Treatment & $\begin{array}{l}\text { Population } \\
(\mathrm{N})\end{array}$ & $\begin{array}{l}\text { Pre-test } \\
\text { Mean }\end{array}$ & $\begin{array}{l}\text { Post- } \\
\text { test } \\
\text { Mean }\end{array}$ & $\begin{array}{l}\text { Mean } \\
\text { Gain }\end{array}$ \\
\hline Experimental & PBL & 42 & 7.81 & 14.41 & 6.6 \\
\hline
\end{tabular}

Table 2 revealed that the students' academic performance was better when taught Digital electronics using problem-based learning as shown in the post-test Mean score (14.41) which was much higher than the pre-test Mean Score (7.81) giving a Mean Gain of 6.6. This finding agrees with Abdullah, Tarmizi, and Abu (2010) and Marum (2009) who in their separate studies report that Problem-based learning has positive effects on students learning and their overall academic achievements. Thus, PBL is the teaching method that yields much results in terms of students' academic achievements in engineering courses. Table 3 indicates that the post-test mean of the experimental group was 14.41 and that of the control group was 11.71. Thus, the mean gain was obtained as 2.7 in favour of the experimental group.

Table 3. Post-test mean gain of students taught Digital electronics with conventional and PBL methods

\begin{tabular}{lllll}
\hline \multicolumn{1}{c}{ Group } & Treatment & $\mathbf{N}$ & Post-test Mean & Mean Gain \\
\hline Experimental & PBL & 42 & 14.41 & 2.7 \\
Control & $\begin{array}{l}\text { Lecture } \\
\text { method }\end{array}$ & 42 & 11.71 & \\
\hline
\end{tabular}

${ }^{\mathrm{c}}$ Field Report, 2019.

Table 3 indicated that students' academic performance in Digital electronics when taught using Problem-based learning was higher than their performance when taught via conventional method as 
shown in the mean Gain of 2.7 with the experimental group on the lead. This finding further reveals that problem-based learning leads to higher students' achievement in engineering courses. This finding agrees with Tavukçu (2006) who posits that problem-based learning enhances the overall efficiency of the learners in cognitive, affective and psychomotor domains of educational objectives. Hence, problem based learning could be regarded as a unified instructional approach applicable whenever teachers want to achieve all-round development of students. Table 4 shows that at degree of freedom 82 and 0.05 level of significance, the post-test mean of students taught Digital Electronics using PBL and CT were 14.41 and 11.71 respectively. Furthermore, the calculated value of $t$ was obtained as 13.82 while the critical or table value of $t$ yielded 1.98 .

Table 4. T-test analysis on the post-test mean scores of students taught digital electronics using lecture method and PBL

\begin{tabular}{lllllllll}
\hline Group & $\mathbf{N}$ & Mean & $\mathbf{S D}$ & $\mathbf{d f}$ & $\mathbf{A}$ & $\mathbf{t}_{\text {cal }}$ & $\mathbf{t}_{\text {crit }}$ & Decision \\
\hline Experimental & 42 & 14.41 & 0.91 & & & & & \\
& & & & 82 & 0.05 & 13.82 & 1.98 & Rejected \\
Control & 42 & 11.71 & 0.88 & & & & & \\
\hline
\end{tabular}

Table 4 showed that the post-test mean score of students taught Digital electronics with PBL (14.41) was higher than the Mean score of students taught Digital electronics using conventional method of teaching. This finding revealed that there is a significant difference in the performances of the two categories of students when taught Digital electronics using conventional teaching method and Problem-based learning in Ken Saro-Wiwa Polytechnic, Bori, Rivers State, South-South, Nigeria. Furthermore, this finding shown that students performed better after receiving treatment in the form of Problem-based learning. Therefore, the null hypothesis which stated that there is no significant difference between the post-test Mean scores of students taught Digital electronics using conventional teaching method and Problem-based learning in Ken Saro-Wiwa Polytechnic, Bori, Rivers State, South-South, Nigeria was rejected. This finding was supported by the report of Demirel and Dağyar (2016), that PBL as a teaching-learning approach is capable of promoting students' academic achievements having positive effects on student attitude. Again, this finding shares a page with Santos-Martin et. al. (2012) who describe Problem-based learning as a teaching strategy that assists students in conceptualizing diverse engineering fundamentals. Finally, this finding equally agrees with Walker and Leary (2009) who posit that Problem-based learning help students to work assiduously towards the attainment of educational objectives.

\section{Conclusion}

Based on the findings of the study, technology and engineering lecturers need to re-consider the use of student-centred teaching approaches to instructional delivery in engineering and technological courses in polytechnics. The reason is that since effective instructional delivery leads 
to effective learning, only the teaching methods that encourages students' active participation in the teaching-learning process can improve their academic achievements. Thus, Digital Electronic lecturers in tertiary institutions are enjoined to apply problem-based learning and other studentcentred teaching strategies in teaching the students so as to achieve an improvement in students' learning and overall academic achievements.

Based on the study findings, the following recommendations were suggested:

- The Polytechnic Management should enforce mandatory application of appropriate studentcentred instructional methods by engineering technology lecturers in order to inculcate relevant problem-solving and other pertinent skills in the students.

- Students should be given technical problems to proffer solutions to as this will expose them to issues warranting the application of problem-solving and other relevant skills needed for employment upon graduation.

- Problem-based learning application should not be limited to only engineering courses rather it should also be extended to other technical courses taught in polytechnics and other technology institutions.

Government should provide the necessary equipment, tools and materials in addition to making the learning environment conducive for effective teaching and learning capable of improving students' academic achievement.

\section{Acknowledgements}

The author sincerely appreciates Prof. P. C. Okwelle and Prof. S. T. Puyate of the Department of Vocational and Technology Education, Rivers State University, Port Harcourt, Nigeria for their mentorship, support and guidance which saw to the successful completion of this article. The author equally thanked his family and colleagues who in one way or the other supported the article from its preparatory stage to final stage of publication. The author sincerely appreciates both lecturers and final year students of electrical and electronic engineering (telecommunications and electronics option) of Ken Saro-wiwa Polytechnic, Bori for making themselves available all through the period of the study because without them, the study would not have seen the light of the day.

\section{References}

Abdullah, N. I., Tarmizi, R. A., and Abu, R. (2010). The effects of problem-based learning on mathematics performance and affective attributes in learning statistics at form four secondary level. Procedia Social and Behavioral Sciences, 8, 370-376.

Akınoğlu, O., and Tandoğan, R. O. (2007). The effects of problem-based active learning in science education on students' academic achievement, attitude and concept learning. Eurasia Journal of Mathematics, Science and Technology Education, 3(1), 71-81.

Albanese, M., and Mitchell, S. (1993). Problem-based learning: A review of literature on its outcomes and implementation issues. Academic Medicine, 68(1), 52-81. 
Arends, R. I. (1998). Learning to teach. Boston, USA: McGrow Hill.

Barrows, H. (2002). Is it truly possible to have such a thing as PBL? Distance Education, 23(1), 119122.

Beringer, J. (2007). Application of problem based learning through research investigation. Journal of Geography in Higher Education, 31(3), 445-457.

Bhatti, P. T., and McClellan, J. H. (2011). A cochlear implant signal processing lab: Exploration of a problem-based learning exercise. IEEE Transactions on Education, 54(4), 628-636.

Çelik, E., Eroğlu, B., and Selvi, M. (2012). The effect of problem based learning approach in science education on students' academic achievement, and attitudes toward science and technology course. Kastamonu Education Journal, 20(1), 187-202.

Chukwudebe, G. A., Chika, I. E., and Onojo, J. O. (2006). Understanding Digital Logic Techniques and Systems. Nnewi: M C Computer Press.

Colliver, J. A. (2000). Effectiveness of problem-based learning curricula: Research and theory. Academic Medicine, 75(3), 259-266.

Delisle, R. (1997). Use problem-based learning in the classroom. USA: ASCD.

Demirel, M., and Dağyar, M. (2016). Effects of Problem-Based Learning on Attitude: A Meta-Analysis Study. Eurasia Journal of Mathematics, Science \& Technology Education, 12(8), 21152137.

Diraso, D., Manabete, S., Amalo, K., Mbudai, D., Arabi, S., and Jaoji, A. (2013). Evaluation of students' performance in technical and engineering drawing towards an effective career choice in engineering and technical and vocational education. International Journal of Educational Research and Development, 2(4) 89-97.

Dooley, C. (1997). Problem-centered learning experiences: Exploring past, present and future perspectives. Reaper Review, 19(4), 192-195.

Duch, B. J., Groh, S. E., and Alen, D. E. (2001). The power of problem-based learning, a practical "how to" for teaching undergraduate courses in any discipline. Sterling, VA: Stylus.

ECSA. (2014). Home Page. [Online]. Retrieved from: http://www.ecsa.co.za/ [Accessed on: 05 January, 2020].

Edens, K. M. (2000). Preparing problem solvers for the 21st century through Problem-based Learning. College Teaching, 48(2), 55-60.

Ekezie, A. I. A., and Owo, O. T. (2019). Assessment of the capacity building needs of agricultural science teachers for innovative instructional delivery in secondary schools in Rivers State, Nigeria. Innovation of Vocational Technology Education, 15(2), 43-57.

Fajimi, O. (2005). Problems encountered in the teaching and learning of technical drawing in Junior Secondary Schools of Lagos State in Nigeria. The Journal of Nigerian Association of Teachers of Technology, 5(1), 145-149.

Felder, R. M., and Brent, R. (1994). Cooperative learning in technical courses: Procedures, pitfalls, and payoffs. ERIC Document Reproduction Service ED-377038). [Online]. Retrieved from: www.ncsu.edu/effective teaching [Accessed on: 05 January, 2020].

Floyd, T. L. (2002). Digital Fundamentals. 7th Edition. New Delhi, India: Pearson Education. 
Hastings, D. (2003). Case study: Problem based learning and the active classroom. [Online]. Retrieved from: http://www.tag.ubc.ca/facdev/services/newsletter/97/active.html [Accessed on: November 14, 2019].

Hmelo-Silver, C. E. (2004). Problem based learning: What and how to students learn? Educational Psychology Review, 16(3), 235-266.

House, K. (2000). Mathematical problem solving in a grade 2 classroom. A Report of an Internship, 52-57.11. Memorial University of Newfoundland. [Online]. Retrieved from: www.researchgate.net/publication/35736015 [Accessed on: December 22, 2019].

Johnstone, K. M., and Biggs, S. F. (1998). Problem-based learning: introduction, analysis and accounting curricula implications. Journal of Accounting Education, 16(3), 407-427.

Jones, L. (1996). Basic electronics for tomorrow's world. Cambridge Low Price Edition. Great Britain, Cambridge University Press.

Kaptan, F., and Korkmaz, H. (2001). Problem based learning approach in science education. Hacettepe University Journal of Education, 20, 185-192.

Kaufman, D. M., and Mann, K. V. (1997). Basic sciences in problem-based learning and conventional curricula: students' attitudes. Medical Education, 31(3), 177-180.

Koçakoğlu, M. (2008). The effect of problem based Learning and Motivational styles on students' academic success and attitudes towards Biology Course. (Unpublished Doctoral Thesis) Turkey: Gazi University.

Leary, H. M. (2012). Self-directed learning in problem-based learning versus traditional lecturebased learning: A meta-analysis. All Graduate Theses and Dissertations. [Online]. Retrieved from: http://digitalcommons.usu.edu/etd/1173 [Accessed on: 11/12/2019].

Marum, T. (2009). PBL vs. DI: Which increases student achievement and attitude? (Unpublished Master Thesis), USA: Western Governors University.

Mierson, S., and Parikh, A. A. (2000). Stories from the field: Problem-based learning from a teacher's and a student's perspective. Change: The Magazine of Higher Learning, 32(1), 20-27.

National Board for Technical Education. (2001). Curriculum and Course Specifications for Higher National Diploma Programme in Electrical Engineering. Kaduna, Nigeria: UNESCO- Nigeria Project.

Okwelle, P. C., and OWO, O. T. (2018). Effects of Collaborative Learning on Academic Performance of Students in Technical Drawing in Rivers State University, Port Harcourt, Nigeria. International Journal of Educational Benchmark, 9(1), 77-87.

Özdil, G. (2011). Effects of problem based learning approach on students? Success in teaching the concepts of area and perimeter in seventh grade in primary schools. (Unpublished Master Thesis), Turkey: Kastamonu University.

Reynolds, J. M., and Hancock, D. R. (2010). Problem-based learning in a higher Education environmental biotechnology course. Innovations in Education and Teaching International, 47(2), 175-186.

Ribeiro, L. R. C., and Mizukami, M. G. N. (2005). Problem-based learning: A student evaluation of an implementation in postgraduate engineering education. European Journal of Engineering Education, 30, 137-149. 
Saban, A. (2004). Teaching-learning process: New theories and approaches. Ankara: Gazi.

Santos-Martin, D., Alonso-Martinez, J., Eloy-Garcia Carrasco, J., and Arnaltes, S. (2012). ProblemBased Learning in Wind Energy Using Virtual and Real Setups. IEEE Transactions on Education, 55(1), 126-134.

Savery, J. R. (2006). Overview of problem-based learning: Definitions and distinctions. Interdisciplinary Journal of Problem-Based Learning, 1(1), 3.

Schwarts, P., Mennin, S., and Webb, G. (Eds.) (2001). Problem-based learning: Case studies, experience and practice. London: Kogan Page.

Sedha, R. A. (2010). A Textbook of Digital Electronics. Revised edition. New Delhi: S. Chand \& Co. Ltd.

Sevening, D., and Baron, M. (2003). A comparison of traditional teaching methods and problembased learning in an addiction studies class. Journal of Teaching in the Addictions, 1(2), 27-42.

Sifoğlu, N. (2007). The effects of constructivism and problem-based learning on students' success in the teaching the topic heritage' at the 8th grade. (Unpublished Master Thesis), Turkey: Gazi University.

Swart, A. J. (2010). Evaluation of Final Examination Papers in Engineering: A Case Study Using Bloom's Taxonomy. IEEE Transactions on Education, 53(2), 257-264.

Swart, A. J. (2014). Using Problem-Based Learning to Stimulate Entrepreneurial Awareness among Senior African Undergraduate Students. Eurasia Journal of Mathematics, Science \& Technology Education, 10(2), 125-134.

Tavukcu, K. (2006). The effects on the learning outcomes of problem based learning in science instruction. (Unpublished Master Thesis), Turkey: Zonguldak Karaelmas University.

Tseng, K. H., Chiang, F. K., and Hsu, W. H. (2008). Interactive processes and Learning Attitudes in a web-based problem-based learning (PBL) platform. Computers in Human Behavior, 24(3), 940-955.

Uden, L. (2006). Technology and problem-based learning. C. Beaumont (Ed.). USA: IGI Global.

Üstün, U. (2012). To what extent is problem based learning effective as compared to traditional teaching in science education? A meta-analysis study. (Unpublished Doctoral Thesis), Turkey: Middle East Technical University.

Vanwasi, A. K., and Mithal, G. K. (2004). Pulse and Digital Electronics. New Delhi: Khanna Publishers.

Walker, A., and Leary, H. (2009). A problem based learning Meta-Analysis: Differences across problem types, implementation types, disciplines, and assessment levels. Interdisciplinary Journal of Problem-based Learning, 3(1), 6-28.

Walton, H. J., and Matthews, M. B. (1989). Essentials of problem-based learning. Medical Education, 23. 